Egyptian Journal of Aquatic Biology \& Fisheries

Zoology Department, Faculty of Science,

Ain Shams University, Cairo, Egypt.

ISSN $1110-6131$

Vol. 25(4): 573 - 586 (2021)

www.ejabf.journals.ekb.eg

\title{
Length-Weight Relationship and Condition Factor of white grouper Epinephelus aeneus ( Geoffroy Saint Hilaire, 1817) in the Mediterranean coast of Sinai, Egypt
}

\section{Attia A. O. El- Aiatt ${ }^{1}$, Kariman A.Sh. Shalloof ${ }^{1, *}$ and Shymaa A.A. Omar ${ }^{2}$}

1. National Institute of Oceanography and Fisheries, Egypt

2. General Authority for Fish Resources Development, Egypt

*Corresponding Author: dr_kariman88@yahoo.com

\begin{abstract}
ARTICLE INFO
Article History:

Received: Aug. 18, 2021

Accepted: Aug. 24, 2021

Online: Aug. 28, 2021
\end{abstract}

Keywords:

Length weight

relationship,

Condition factor,

Epinephelus aeneus,

Mediterranean coast

\section{ABSTRACT}

This study describes the first documented length-weight relationship and condition factor of the white grouper Epinephelus aeneusin on the Mediterranean coast of Sinai, Egypt. A total of 697 specimens with an average length of $34.6 \mathrm{~cm}$ and weight $593.0 \mathrm{~g}$ were monthly sampled from January 2019 to December 2020. For each specimen, length $(\mathrm{cm})$ and weight $(\mathrm{g})$ were measured. The length-weight relationship was described by the equation: $\mathrm{W}=\mathrm{a} \mathrm{L}^{\mathrm{b}}$, while the condition factor was calculated using the equation: $\mathrm{K}=100\left(\mathrm{~W} / \mathrm{L}^{3}\right)$. Condition factor was calculated monthly and according to the length group. The values of the regression coefficients obtained for the length-weight relationship were 2.9327, 2.8847 and 3.1141 having $\mathrm{r}^{2}$ values of $0.9392,0.9438$ and 0.9616 for males, females and combined sexes of the studied species, respectively. Condition factor $(\mathrm{K})$ of males, females and combined sexes of $E$. aeneus was fluctuated monthly and related to lengths groups. It was concluded that general well-being was observed for this species, since condition factor more than $1(\mathrm{~K}=1.20,1.30$ and 1.20 for males; females and combined sexes, respectively). The current study's findings can be used as baseline data for this species in the examined area.

\section{INTRODUCTION}

Groupers are bottom-associated fishes found in the tropical and subtropical waters of all oceans. Most species occur on coral reefs, but some live in estuaries or on rocky reefs. Adults of Groupers are generally associated with rocky bottoms, although juveniles are found in seagrass beds, and adults of a few species prefer sandy or silty areas. Some species occur in depths of 100 to $200 \mathrm{~m}$ (occasionally to $500 \mathrm{~m}$ ); however, the majority inhabits depths less than $100 \mathrm{~m}$, and juveniles are often found in tide- pools (Heemstra and Randall, 1993)

Turan et al., (2017) reported that the white grouper Epinephelus aeneus has remarkable economic importance in Epinephelus genus for the Mediterranean fisheries. 
Epinephelus aeneus (Geoffroy Saint-Hilaire, 1817) can be found throughout the southern Mediterranean (up to $44^{\circ} \mathrm{N}$ in the Adriatic Sea), along the Atlantic coasts of Portugal, Spain, and Africa, down to southern Angola (Thierry et al., 2008 \& Pollard et al., 2018).

E. aeneus is of considerable economic importance in fisheries and caught with hooks and lines and by trawls. The species is listed as Near Threatened both in the Mediterranean Regional Red List and Global Red List of IUCN (Abdul Malak et al., 2011).

A fish Length Weight Relationship is an important tool in fisheries biology and stock assessments since it allows for the determination of fish age, structure, and health by providing many details about its seasonal cycles and affecting components of biotic and abiotic parameters (Ayoade and Ikulala, 2007).

Length-weight relationship of fish is widely known as an important tool in fisheries science especially in ecology and population dynamic (Abdoli and Rasooli, 2008). This relation provides useful information on fish species within a given geographic region (Morato et al., 2001; Aura et al., 2011). In fish, size is generally more biologically relevant than age, mainly because several ecological and physiological factors are more size-dependent than they are age-dependent. Therefore, variability in size has important implications in fisheries science and population dynamics (Erzini, 1994), and is one of the most common measurements in fisheries data (Mendes et al., 2004).

Pauly (1983) reported the importance of length-weight relationship in the calculation of an equation of growth in length into an equation of growth in weight. Whereas Arsalan et al. (2004) stated that, it is usually easier to measure length than weight and weight can be predicated later on using the length-weight relationship which helps among other fish given its definite length. The study of length-weight relationship is of paramount importance in fishery science, as it assists in understanding the general well-being and growth patterns in a fish population. According to Bashir et al. (1993), the length-weight relationship of fish varies depending upon the condition of life in aquatic environment. Length-weight relationship is of great importance in fishery assessments (Haimovici and Velasco, 2000).

This relation can also be used for deriving comparisons between different stages in life history and between fish populations from regions or habitat groups ( Gonçalves $\boldsymbol{e t}$ al. 1996), and tracking seasonal variations in fish growth (Richter ,2007). Length-weight relationships can also be used to know the growth pattern of the fish in the culture system. It is also used to estimate fish biomass from length frequency distributions, infer fish condition (Petrakis and Stergiou, 1995).

Condition factor is required to fishery biologists to describe the condition plumpness, or well-being of fish (Ogongo et al., 2015). It is used to express fish condition in numerical terms, such as degree of well-being, fatness, or relative robustness. Fish condition factor is a measure that is commonly used to understand fish 
survival, reproduction, maturity, and health (Le Cren, 1951), and often, it can be utilized as a good indicator of water quality or the overall health of fish populations in a given area or ecosystem (Tsoumani $\boldsymbol{e t}$ al., 2006). It was used to assess the degree of well-being of $E$. aeneus in the study area which provides information on the environmental quality and suitability (polluted or non-polluted of the ecosystem (Le Cren 1951 and Guidelli $\boldsymbol{e t}$ al. 2011).

The length-weight relationships and condition factors are two of the most important biological aspects to assess the growth rate and fish condition (Muchlisin, 2010). Therefore, the information of length-weight relationships and condition factors are important to plan a better conservation strategy of the fishery resources (Muchlisin et al., 2015).

Grouper remains poorly studied in Egypt, despite their economic and ecological importance. The main objective of this work is to assess the growth pattern of the white grouper Epinephelus aeneus harvested from Mediterranean North Saini coast. This study describes the first documented data on length- weight relationship and condition factor of white grouper E. aeneus in the Mediterranean coast of Sinai, Egypt. Such data is crucial for the management of this fish species.

\section{MATERIALS AND METHODS}

\section{Study area and data collection:}

A total of 697 E. aeneus (Fig.1) was obtained from the fish market in Al-Arish. As the fish merchants bring the fish from fishing boats operating in the Mediterranean off the coast of Sinai, (Fig. 2), which exit at the Port Said seaport.
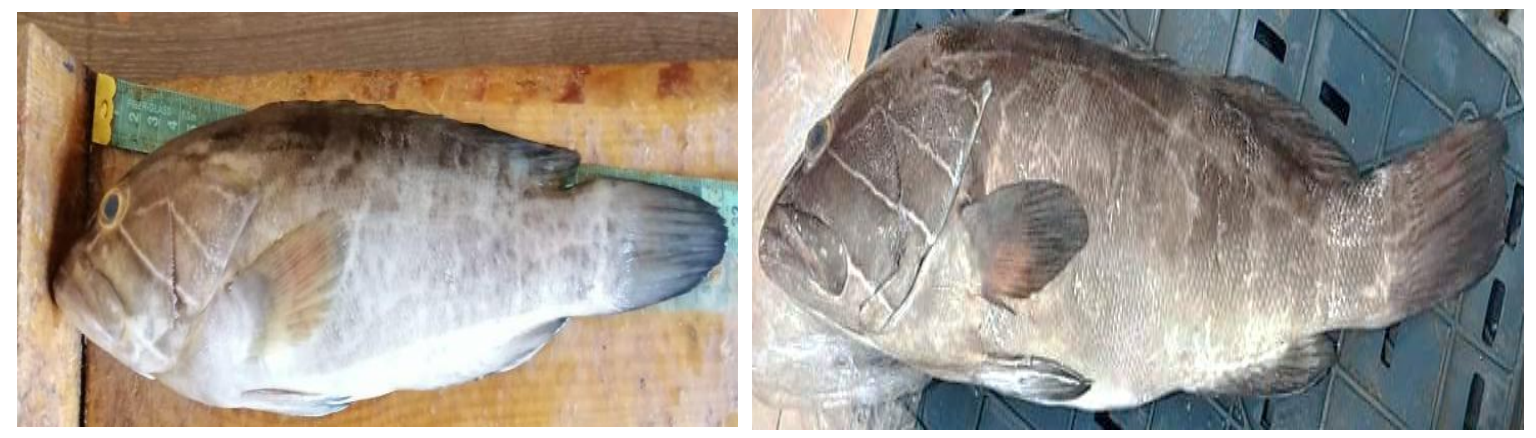

Fig. 1. White grouper Epinephelus aeneus from the Mediterranean coast of Sinai, Egypt 


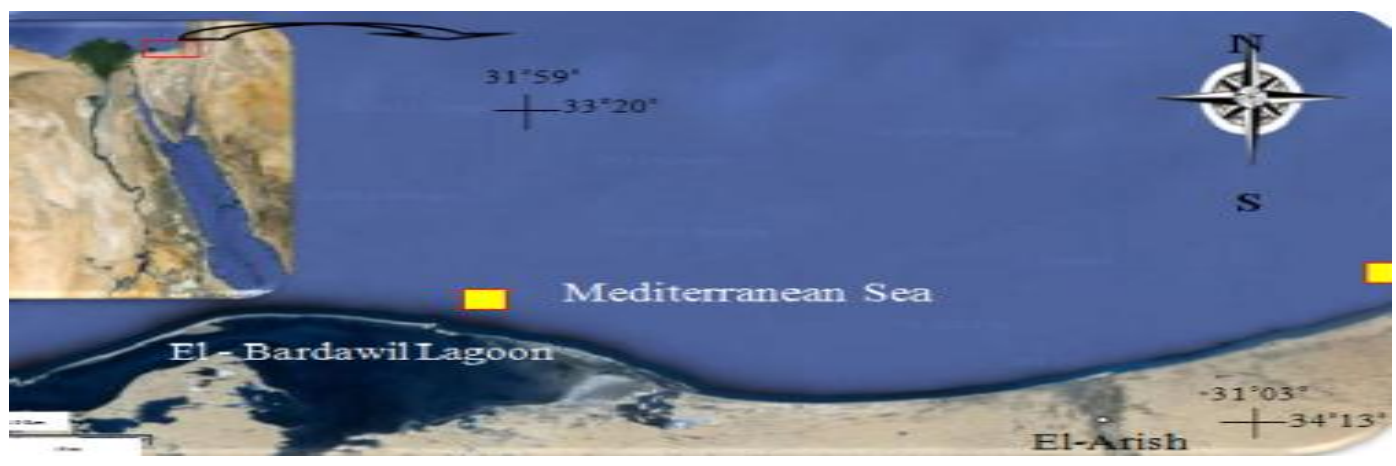

Fig. 2. Study area at Mediterranean coast of Sinai

The fish samples were collected monthly from January 2019 to December 2020. Samples were temporarily placed in cooling box filled with ice and transported to the laboratory. For each individual, the total length (TL, cm) and total weight (TW, g) were measured. The growth pattern was calculated using the formula based on Le Cren (1951) as follow: $\mathrm{W}=\mathrm{a} \mathrm{L}^{\mathbf{b}}$, where, $\mathrm{W}$ is total body weight $(\mathrm{g}), \mathrm{L}$ is total length $(\mathrm{cm})$ and (a) is geometric coefficient, (b) is slope of the regression model.

Fulton's condition factor $(K)$ : Fulton's condition factor $(\mathrm{K})$ was calculated according to Hile (1936) equation as per formula given below:

$\mathrm{K}=(\mathrm{W} * 100) / \mathrm{L}^{3} \quad$ Where, $\mathrm{W}=$ weight of fish $(\mathrm{g}), \mathrm{L}=\mathrm{Length}$ of fish $(\mathrm{cm})$ Condition factor $(\mathrm{K})$ was calculated monthly and according to different length groups.

\section{RESULTS}

\section{Length - weight relationship:}

The length - weight relationship of 697 specimens (including 169 females and 100 males) of E. aeneus were presented graphically in Figs. 3, 4 and 5. It has been found that, the lengths of combined sexes varying between 20.4 to $61.0 \mathrm{~cm}$ (mean= $34.6 \mathrm{~cm}$ ) and the weight from 94.1 to $2788.9 \mathrm{~g}$ with an average $593.0 \mathrm{~g}$. and the length - weight relationship was: $\mathrm{W}=0.0083 \times \mathrm{L}^{3.1141}$.

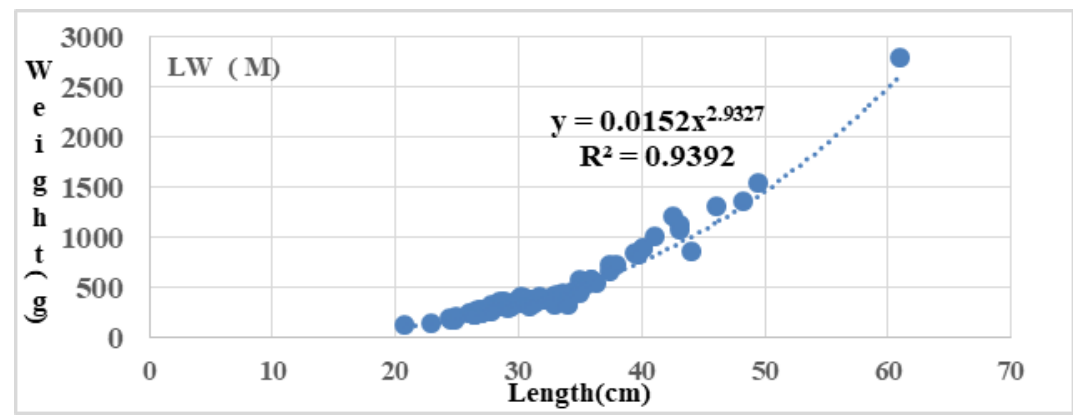

Fig. 3. Length-weight relationship of males of Epinephelus aeneus 


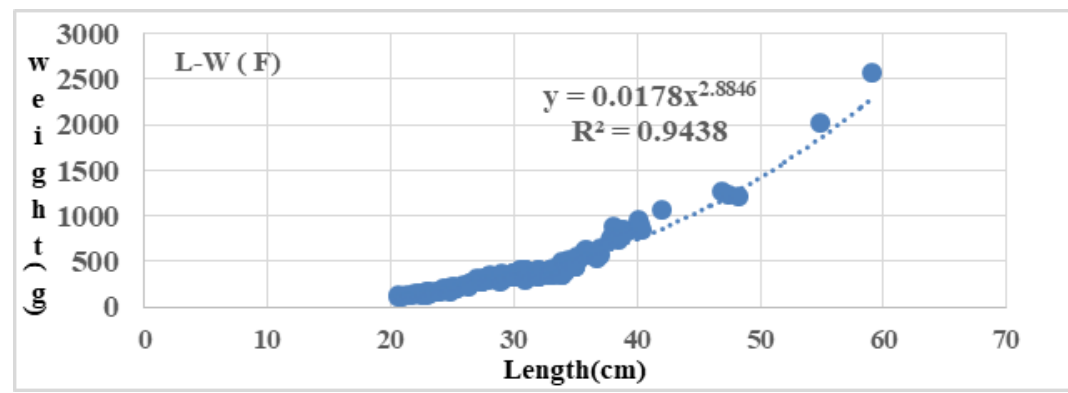

Fig. 4. Length-weight relationship of females of E. aeneus

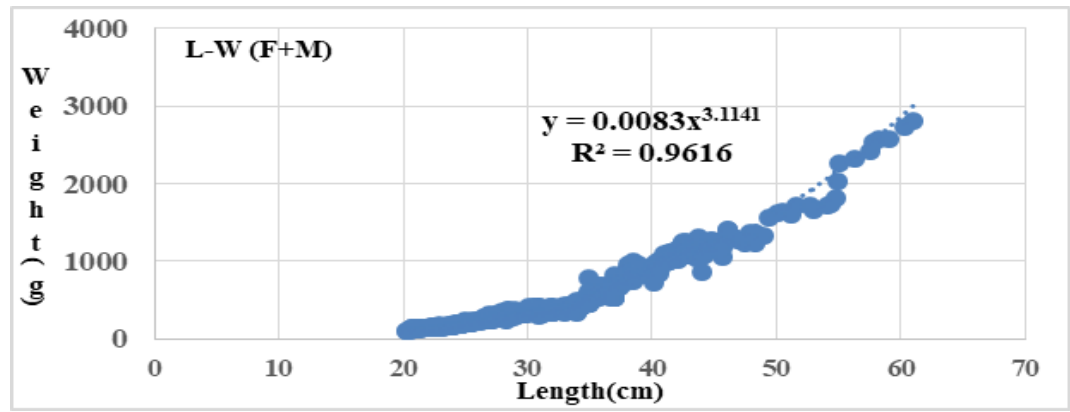

Fig. 5. Length-weight relationship of combined sexes of E. aeneus

\section{Condition factor $(K)$ :}

\subsection{According to different length group:}

Condition factor $(\mathrm{K})$ of males, females and combined sexes of E. aeneus related to lengths groups are represented graphically in figures (6, 7 and 8). Condition factor of males was observed to be less than females and sexes combined. The lowest value of $(\mathrm{K})$ 34 for males was observed in size class 34-34.9 \& 44- $44.9 \mathrm{~cm}$ and the highest one was recorded in size class of $42-42.9 \mathrm{~cm}(\mathrm{~K}=1.6)$.

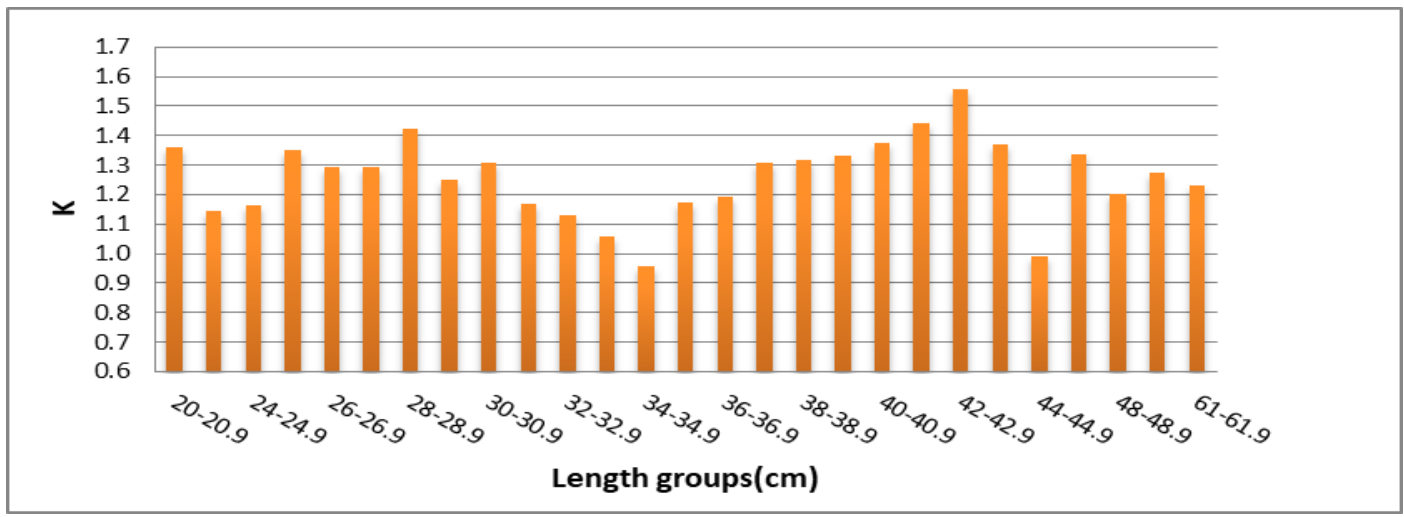

Fig. 6. Condition factor (K) of males of E. aeneus at different length groups 


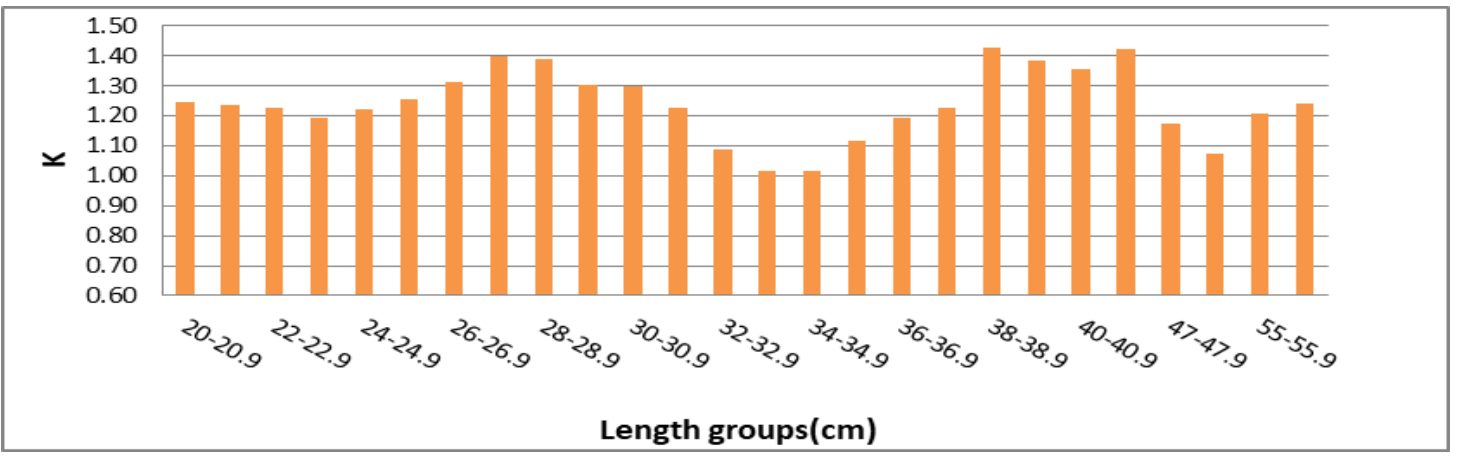

Fig. 7. Condition factor $(\mathrm{K})$ of females of E. aeneus at different length groups

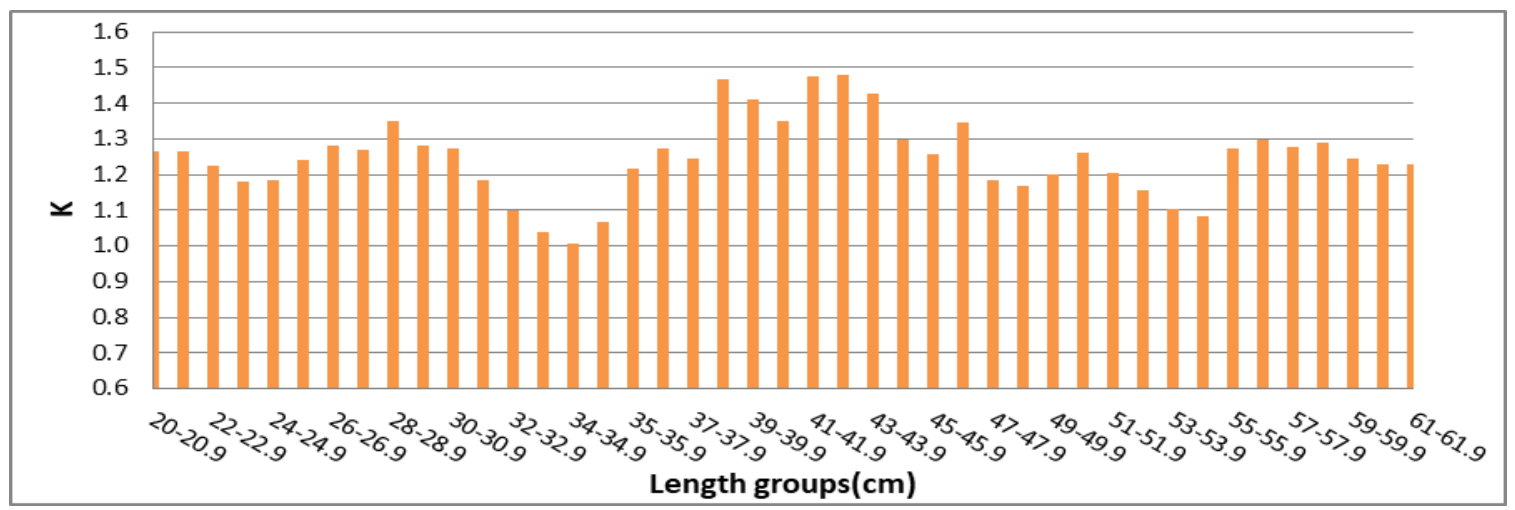

Fig. 8. Condition factor (K) of combined sexes of E. aeneus at different length groups

As it is shown from Fig. 7, the highest value of condition factor $(\mathrm{K})$ of females was recorded at length interval 38.0-38.9 and 42.0-42.9 cm, since $\mathrm{K}=1.43$ and 1.42 respectively. For sexes combined, $\mathrm{K}$ ranged from 1.01 to 1.5 , in size classes $38-38.9 \mathrm{~cm}$ and $42-42.9 \mathrm{~cm}$ respectively with a mean of 1.25 . The lowest value was recorded at length interval 34- 34.9 as shown in Fig. 8.

\subsection{According to different months:}

Figs. 9, 10 and 11 presents condition factor of E. aeneus at different months for males, females and sexes combined respectively. The results show that, the lowest value of " $\mathrm{K}$ " for males was recorded during February and November (1.13 and 1.14 respectively) whearas the highest one during April (1.58). The lowest values of $\mathrm{K}$ for female was recorded during February, October and December (1.2) and the highest value of 1.43 was observed during August. Concerning sexes combined, the lowest value (1.18) and the highest value (1.47) was recorded during February and April, respectively. 


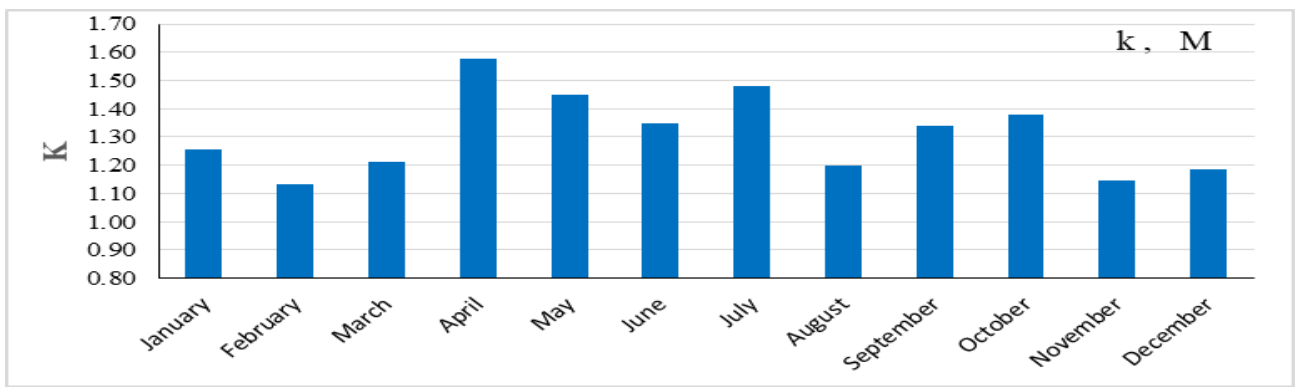

Fig. 9. Monthly variations in condition factor $(\mathrm{K})$ of males of Epinephelus aeneus

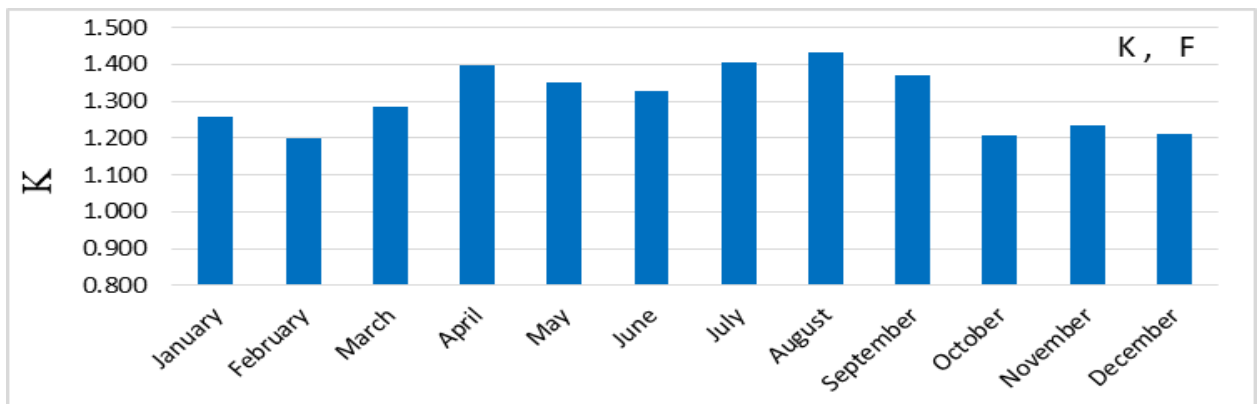

Fig. 10. Monthly variations in condition factor $(\mathrm{K})$ of females of E. aeneus

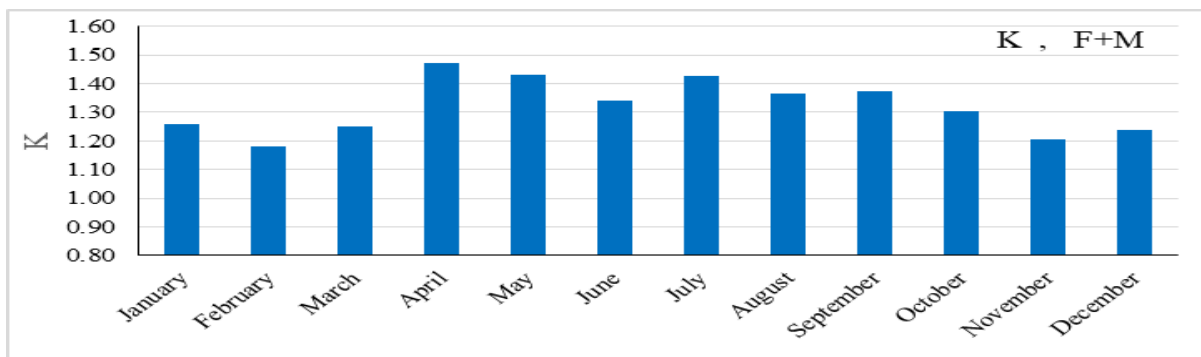

Fig. 11. Monthly variations in condition factor $(\mathrm{K})$ of combined sexes of E. aeneus

\section{DISCUSSION}

The main concern of the paper was to study length-weight relationship and condition factor of white grouper Epinephelus aeneus, (Geoffrey Saint Hilaire, 1817) in the Mediterranean coast of Sinai, Egypt. The mathematical relationship of length with the weight of fish is considered as an important tool for interconversion (Lagler, 1956) and to deduce an inference regarding the suitability of the environment for any particular species (Maceina and Murphy, 1988). This relationship also provides some additional information related to spawning, growth, feeding, gonadal development and maturity time of the fish (Dawe, 1988\& Maceina and Murphy, 1988).

In the present study, 697 specimens (including 169 females and 100 males) of $E$. aeneus were presented graphically to study length- weight relationship. As a result of low naturally occurring, the male sex ratio of the E. aeneus had limited ability to collect 
representative sample size, whereas, that male low ratio recognized in many literatures (Pears, 2005; Mishina et al., 2006 and Ogongo et al., 2015).

Lengths and weights of E. aeneus in the present work varying between 20.4 and $61.0 \mathrm{~cm}$ (mean = 34.6) and weight between 94.1 to $2788.9 \mathrm{~g}$ (mean= $593.0 \mathrm{~g})$. Turan et al., (2017) stated that, lengths and weights of E. aeneus from Iskenderun Bay, Northeastern Mediterranean were ranged from 18.5 to 82.6 and from 50.7 to $89.2 \mathrm{~cm}$ \& from 29.13 to 6750 and 1443.6 to $8600 \mathrm{~g}$ for females and males, respectively. Özbek et al (2013) reported that the Lengths of E. aeneus in the Gulf of Antalya, Turkey varies between 10.0 to $101.0 \mathrm{~cm}$ (mean $35.0 \mathrm{~cm}$ ) and the weights varying between 37.0 to $11000 \mathrm{~g}$ (mean $1094.4 \mathrm{~g}$ ). Waly et al., (2015) reported that the total lengths and weights of the white grouper E. aeneus in the south-west coast of Senegal, West Africa ranged from 17.9 to $94.8 \mathrm{~cm}$ and between 62.8 and $10934 \mathrm{~g}$, respectively. These differences may be due to the ecological condition; feeding habits; maturity stages; sampling process and methods of fishing.

The Length-weight relationship is actual index of the condition of fish and alters over the year according to factors namely food availability, feeding rate, gonad (Waly et al., 2015) development and spawning time (Bagenal and Tesch, 1978).

In the present study, length-weight relationship were $\mathrm{w}=0.0152 \mathrm{~L}^{\mathbf{2 . 9 3 2 7}}$, $\mathrm{W}=0.0178 \mathrm{~L}^{\mathbf{2 . 8 8 4 6}}$ and $\mathrm{W}=0.0083 \mathrm{~L}^{\mathbf{3 . 1 1 4 1}}$ for males, females and combined sexes respectively. (b) values of males and females was less than 3, since it was 2.9327 and 2.8846 of both sexes respectively, indicating negative allometric growth pattern.This suggests that either the weight gain was not equal to the length gain or the weight gain was slower than the length gain.

Fish is said to exhibit isometric growth when length increases in equal proportion with body weight, the regression coefficient for isometric growth is ' 3 ' and values greater than ' 3 ' indicates allometric growth (Olurin and Aderibigbe, 2006).

Table 1 presents comparison of length -weight relationships and regression parameters ( $\mathrm{a}$ and $\mathrm{b}$ ) of E. aeneus at different localities. Our results(value of $\mathrm{b}$ ) are lower than that recorded by Magnússon and Magnússon (1987) in Cape Verde coasts \& Cury and Worms (1982) in Senegal. In the other hand, these results were higher than that obtained by Özbek et al., (2013) in Turkey and Fiogbe (2003) in Benin, West Africa, Table 1. Differences in ' $b$ ' values can be attributed to the combination of several factors such as number of studied specimens, habitat, and status of stomach fullness, gonadal maturity, sex, health and overall fish condition, and differences in the observed length ranges of the specimens caught (Abowei et al. , 2009).

In the present study, condition factor $(\mathrm{K})$ of males, females and combined sexes of E. aeneus was fluctuated related to lengths groups. When the average weight of the fish does not increase in direct proportion to the cube of its length, the condition factor is usually reduced (Wooten, 1990). As a result, when $\mathrm{b}=3$, $\mathrm{K}$ remains constant. On the other hand, if the weight increases faster than the length cube, $\mathrm{K}$ increases as well 
(Javaid and Akram, 1972). With the growth of fish, $K$ tends to decrease when the weight increases less than the cube of length (Javaid and Akram, 1972). The mean condition factors for all length groups in the current study were 1.2, indicating that the fish on the North Sinai coast were in good condition. This may be related to the best environmental condition in the area of study. Anene (2005) and Sarkar et al., (2013) noted that condition factor is not constant for a species or population. From a nutritional point of view, there is the accumulation of fat and gonadal development (Le Cren, 1951). $\mathrm{He}$ also reported that, a fish's condition factor represents physical and biological parameters as well as changes caused by interactions between feeding conditions, parasite diseases, and physiological factors. This also indicates the changes in food reserves and therefore an indicator of the general fish condition. Furthermore, body condition offers an alternative to the costly in vitro proximal tissue investigations (Sutton et al., 2000).

Table 1: Comparison of L-W relationships (a and b) of Epinephelus aeneus from different locations.

\begin{tabular}{|c|c|c|c|c|}
\hline Author & Location & $\mathbf{a}$ & $\mathbf{b}$ & $\mathbf{r}^{2}$ \\
\hline Özbek et al., (2013) & Turkey & 0.040 & 2.657 & 0.958 \\
\hline Fiogbe (2003) & Benin, West Africa & & 2.90 & \\
\hline Can et al. (2002) & İskenderun Bay-Turkey & & 2.90 & \\
\hline Özbek et al.,(2013) & Gulf of Antalya, Turkey & 0.040 & 2.657 & 0.958 \\
\hline Waly et al (2015) & Soumbedioune Senegal & 0.013 & 2.96 & 0.98 \\
\hline Waly et al (2015) & Joal Senegal & 0.006 & 2.99 & 0.97 \\
\hline Waly et al (2015) & Mbour Senegal & 0.006 & 3.00 & 0.98 \\
\hline Ceyhan et al., (2009) & southeastern Aegean Sea & 0.0098 & 3.043 & 0.952 \\
\hline $\begin{array}{l}\text { Cury and Worms } \\
\text { (1982) }\end{array}$ & Senegal & & 3.230 & \\
\hline $\begin{array}{l}\text { Magnússon and } \\
\text { Magnússon (1987) }\end{array}$ & Cape Verde coasts & & 3.580 & \\
\hline Sangun et al. (2007) & Turkey & 0.0128 & 2.987 & 0.99 \\
\hline \multirow[t]{3}{*}{ Present study } & Mediterranean coast of Sinai ( males) & 0.0152 & 2.9327 & 0.94 \\
\hline & \begin{tabular}{|l} 
Mediterranean coast of Sinai ( females) \\
\end{tabular} & 0.0178 & 2.8846 & 0.94 \\
\hline & $\begin{array}{l}\text { Mediterranean coast of Sinai(combined } \\
\text { sexes) }\end{array}$ & 0.0083 & 3.1141 & 0.96 \\
\hline
\end{tabular}

Bagenal (1978) and Wootton (1996) reported that fish with higher $\mathrm{K}$ values (> $1)$ are in a better condition than fish with lower $K$ values $(<1)$. In this study, $K$ values in the present study ranged from 1.0 to 1.5 with a mean value of 1.2 . Condition factor is used for comparing the condition, fatness, or well-being of fish, based on the assumption that heavier fish of a given length are in better condition.

The values obtained from the present study showed that, E. aeneus was in good condition. Le Cren (1951) reported that environmental factors, food supply and parasitism have great influence on the health of the fish. Abowei and Davies (2010) 
reported that, the condition factor reflects the well-being of the fish and it gives information on the physiological state of the fish in relation to its welfare.

Ighwela et al. (2011) reported that, when evaluating the duration of gonad maturation and following up on the degree of feeding activity of species to check if it is making appropriate use of its source, the condition factor provides information when comparing two populations living in certain feeding, density, climatic, and other conditions. It is impacted by both environmental conditions and factors such as sex, season, age, and stage of fish development. It can be used as an index to determine the state of an aquatic ecosystem (Edah et al., 2010).

Related to differences in condition factors with different months, the lowest value of the $\mathrm{K}$ was recorded during February in males, females and combined sexes. The highest values of $\mathrm{K}$ in females were recorded in July and August (1.41 and 1.43 respectively).This may be related to the reproductive behavior of the studied species. Desiderà et al., (2019) reported that time of the E. aeneus spawning $\left(24{ }^{\circ} \mathrm{C}\right.$ at $\left.24.7 \mathrm{~m}\right)$, in the Marine Protected Area (MPA) of Tavolara- Punta Coda Cavallo (NE Sardinia, Italy), in the Western Mediterranean Sea as well as over the 2018 summer months (JulySeptember).

Vazzoler (1996) confirmed that lowest $K$ values during the more developed gonadal stages might mean resource transfer to the gonads during the reproductive period. Braga (1986), through other authors, showed that values of the condition factor vary according to seasons and are influenced by environmental conditions. The floodplain is influenced by various biotic and abiotic elements that support the equilibrium of all species in the ecosystem; therefore similar occurrences may occur in the environment under consideration.

\section{CONCLUSION}

Based on the results, it can be concluded E. aeneus was in good condition in the area of study. The findings of our research will assist biologists in understanding the status of this fish and developing culture technology in natural waters, as well as fishery biologists and conservation biologists in the successful development, management, production, and ultimate conservation of Egypt's most popular food fishes.

\section{REFERENCES}

Abdoli, A. and Rasooli P. (2008). Length-weight relationship of 10 Species of fishes collected from Iranian fresh waters, Journal of Applied Itchyology, 22: 156-157

Abdul Malak, D.; Livingstone, S. R.; Pollard, D.; Polidoro, B. A.; Cuttelod, A.; Bariche, M.; Bilecenoglu, M.; Carpenter, K. E.; Collette, B. B.; Francour, P.; Goren, M.; Kara, M. H.; Massutí, E.; Papaconstantinou, C. and Tunesi, L. 
(2011) Overview of the conservation status of the marine fishes of the Mediterranean Sea. IUCN, Gland, Switzerland and Malaga, Spain, 68 pp.

Abowei, J.F.N. and Davies, O.A. (2010). Some population parameters of Clarotes laticeps (Rupell, 1829) from the fresh water reaches of the lower river, Niger Delta, Nigeria. Am. J. Sci. Res., 2: 15-19.

Abowei, J. F. N.; Daviesand, O. A. and Eli, A. A. (2009). Study of the length -weight relationship and condition factor of five fish species from Nkoro River,Niger Delta, Nigeria. Curr. Res. J. Bio. Sci. 1(3): 94-98.

Anene, A. (2005). Condition Factor of Four Cichlid Species of a Man-made Lake in Imo State, Southeastern Nigeria. Turk. J. Fish. Aquat. Sci., 5: 43-47.

Arsalan, M.; Yildirim, A. and Bektas, S. (2004). Length-weight relationship of brown trout, Salmo trutta L., inhabiting Kan stream, Coruh Basin, North-Eastern Turkey. Turk. J. Fish. Aquat. Sci., 4: 45-48.

Aura, M. C.; Munga, C.N.; Kimani, E.N., Manyala, J.O. and Musa, S. (2011). Length-weight relationships for nine deep sea species off the Kenyan coast. PanAmerican Journal of Aquatic Sciences 6: 188-192.

Ayoade, A.A. and Ikulala A.A.A. (2007). Length Weight Relationship, Condition Factor and Stomach Contents of Hemichromis bimaculatus, Sarotherodon melanotheron and Chromidotilapia guentheri (Perciformes: in Eleiyele Lake, South-western Nigeria. Revista de Biología Tropical, 55(3-4), 969-977.

Bagenal, T. B. and Tesch, F. W. (1978). Age and growth In: T. Bagenal, editor, methods for assessment of fish production in fresh waters. IBp handbook No.3 $\left(3^{\text {rd }}\right.$ ed) Black well sci. publications, Oxford. Pp. 101-136 (chapter 5).

Bashir, Z.I.; Bortolotto, Z.A.; Davis, C.H.N.; Berretta, A.; Irving, J.; Seal, A.J.; Henley, J.M.; Jane, D.E.; Watkins, J.C. and Collingridge, G.L. (1993). Induction of LTP in the hippocampus needs sympatric activation of glutamate metabotropic receptors. Nat., 363: 347-350.

Braga, F.M.S. (1986). Estudo entre o fator de condicao e relação peso/comprimento para alguns peixes marinhos. Rev. Brasil. Biol., 46(2): 339-346.

Can, F.; Başusta, N. and Çekiç, M. (2002). Weight-length relationships for selected fish species of the small-scale fisheries off the south coast of Iskenderun Bay. Turk. J. Vet. Anim. Sci., 26: 1181-1183.

Ceyhan, T.; Akyo, O. and Erdem, M. (2009). Length-Weight Relationships of Fishes from Gökova Bay, Turkey (Aegean Sea). Turk. J. Zool., 33: 69-72.

Cury, P. and Worms, J. (1982). Pêche, biologie et dynamique du thiof (Epinephelus aeneus, Geoffroy Saint-Hilaire, 1817) sur les côtes sénégalaises. Document Scientifique du Centre de Recherches Océanographiques de Dakar-Thiaroye. Dakar, Sénégal.

Dawe, E. G., (1988). Length-weight relationships for short finned squid in Newfound and the effect of diet on the condition and growth. Trans. Am. Fish. Soc., HI: 591599.

Desiderà, E.; Magnani, L.; Navone, A., Guidetti, P. and Mazzoldi, C. (2019). First direct evidence of reproductive behaviour of the white grouper, Epinephelus aeneus (Geoffroy Saint-Hilaire, 1817). Medit. Mar. Sci., 20/2, 2019, 326-330 
Edah, B.A.; Akande, A.O.; Ayo-Olalusi, C. and Olusola, A. (2010). Computed the wet weight-dry weight relationship of Oreochromis niloticus (Tilapia). Int. J. Food Safety, 12: 109-116.

Erzini , K. (1994). An empirical study of variability in length at age of marine fishes. Journal of Applied Ichthyology 10: 17-41.

Fiogbe, E.D. (2003). Morphometric relationships of commercially important fish species from Benin. In: Palomares MLD, Samb B, Diouf T, Vakily JM, Pauly D (eds) Fish Biodiversity: Local Studies as Basis for Global Inferences, pp. 25-30.

Gonçalves, J.M S.; Bentes, L.; Lino, P.G.; Ribeiro, J.; Canario, A.V.M. and Erzini, K. (1996).Weight-length relationships for selected fish species of the small-scale demersal fisheries of the south and south-west coast of Portugal. Fish. Res., 30: 253-256.

Guidelli, G.; Tavechio, W.L.G., Takemoto, R.M. and Pavanelli, G.C. (2011). Relative condition factor and parasitism in anostomid fishes from the floodplain of the Upper Parana River, Brazil. Vet Parasitol. 177:145-51.

Haimovici, M. and Velasco, G. (2000). Length-weight relationships of marine fishes from southern Brazil. Fishbyte, 23: 19-23.

Haimovici, M. and Velasco, G. (2000). Length-weight relationship of marine fishes from southern Brazil. The ICLARM Quarty, 23(1): 14-16.

Heemstra, P. C. and Randall, J. E. (1993). FAO Species Catalogue. Vol. 16. Groupers of the World (Family Serranidae, Subfamily Epinephelinae). An annotated and illustrated catalogue of the grouper, rock cod, hind, coral grouper and lyretail species known to date. FAO Fisheries Synopsis, No. 125, 16. Rome, FAO, 382 pp.

Ighwela, A.; Ahmed, B. and Abol-Munafi, B. (2011). Condition factor as an indicator of growth and feeding intensity of Nile Tilapia fingerlings (Oreochromis niloticus) fed on different levels of Maltose. Amer Eurasian. J. Agri. Environ. Sci., 11: 559563.

Javaid, M. Y. and Akram, M. (1972). The length-weight relationship and condition factor of seven fresh water fishes of Pakistan. Bull. Dep. Zool. Univ. Punjab, 6: 127.

Lagler, K. F., (1956). Freshwater Fishery Biology. Wm. C. Brown Company, Dubuque, $421 \mathrm{pp}$.

Le Cren, C.D. (1951). The Length-Weight Relationship and Seasonal Cycle in Gonad Weight and Condition in Perch, Perca fluviatilis. Journal of Animal Ecology, 20, 201-219.

Maceina, M. 'J. and Murphy, B. R., (1988). Variation in the weight-to-length relationship among Florida and Northern large mouth bass and their intraspecific Fl hybrid. Trans. Am. Fish. Soc., 117: 232-237.

Magnússon, J. and Magnússon, J.V.V. (1987). ICEIDA/Cape Verde Islands Fisheries Project, survey of demersal fish resources in the waters of Cape Verde Islands. (5th ed.). Cape Verde.

Mendes, B.; Fonseca, P. and Campos, A. (2004) .Weight length relationships for 46 fish species of the Portuguese west coast. Journal of Applied Ichthyology 20: 355361. 
Morato, T.; Afonso, P.; Loirinho, P., Barreiros, J.P.; Sanstos, R.S. and Nash, R.D.M. (2001). Length weight relationships for 21 costal fish species of the Azores, North-eastern Atlantic. Fisheries Research 50: 297-302.

Mishina, H., B.; Gonzares, H.; Pagaliawan, Motekh , M., and Kohno, H.. (2006). Reproductive Biology of Blacktip Grouper, Epinephelus Fasciatus, in Sulu Sea, Philippines. Societe francojaponaise d'oceanographie, Tokyo. La mer 44: 23-31.

Muchlisin, Z.A. (2010). Diversity of freshwater fishes in Aceh with emphasis on several biological aspect of the depik (Rasbora tawarensis) an endemic species in Lake Laut Tawar. Ph.D thesis, Universiti Sains Malaysia, Penang. 275 pp.

Muchlisin, Z.A.; Batubara, A.S.; Siti-Azizah, M.N.; Adlim, M., Hendri, A., Fadli, N.; Muhammadar, A.A. and Sugianto, S., (2015). Feeding habit and length weight relationship of keureling fish, Tor tambra Valenciennes, 1842 (Cyprinidae) from the western region of Aceh Province, Indonesia. Biodiversitas, 16(1): 89-94.

Muchlisin, Z.A.; Musman, M. and Siti Azizah., M.N. (2010). Length-weight relationships and condition factors of two threatened fishes, Rasbora tawarensis and Poropuntius tawarensis, endemic to Lake Laut Tawar, AcehProvince, Indonesia. Journal of Applied Ichthyology, 26: 949-953.

Ogongo, B.O.; Mwachiro, E.C. and Fulanda, B.M. (2015). Population Structure, Condition and Length-Weight Relationships of Ten Vulnerable Epinephelus Genus Groupers off Kenyan South Coast Indian Ocean Marine Waters. Ecologia, 5: 2230.

Olurin, K.B. and Aderibigbe, O.A. (2006). Length-weight relationship and condition factor of pond reared Oreochromis niloticus. World Journal of Zoology, 1 (2): 8285

Özbek, E.O.; Kebapçığlu, T. and Çardak, M. (2013).Spatio-temporal patterns of abundance, biomass and length-weight relationship of white grouper, Epinephelus aeneus (Geoffroy Saint-Hilaire, 1817) (Pisces: Serranidae) in the Gulf of Antalya, Turkey (Levantine Sea). J. Black Sea/Medit. Environ., 19(1): 23-45.

Pauly, D. (1983). Some Simple methods for the assessment of tropical fish Stock. FAO Fish. Technical Paper.

Pears, R. J. (2005). Comparative Demography and Assemblage Structure of Serranid Fishes: Implications for Conservation and Fisheries Management. Ph. D Thesis, James Cook University, 212pp.

Petrakis, G. and Stergiou, K.I. (1995). Weight-length relationships for 33 fish species in Greek waters. Fish. Res., 21: 465-469.

Pollard, D.A.; Francour, P. and Fennessy, S.T., (2018). Epinephelus aeneus. The IUCN Red List of Threatened Species 2018: e.T132722A100459597.

Richter, T.J. (2007). Development and evaluation of standard weight equations for bridgelip suckers and large scale suckers. N. Am. J. Fish. Manage., 27(3): 936-939.

Sangun, L.; Akamca, E. and Akar, M. (2007). Weight-length relationships for 39 fish species from the north-eastern Mediterranean coast of Turkey. Turk. J. Fish. Aquat. Sci., 7: 37-40.327

Sarkar, U.K.; Khan, G.E.; Dabas, A.; Pathak, A.K.; Mir, J.I.; Rebello, S.C.; Pal, A. and Singh, S.P. (2013). Length weight relationship and condition factor of selected freshwater fish species found in River Ganga, Gomti and Rapti, India. J. Environ. Biol., 34: 951-956. 
Sutton, S.G.; Bult, T.P. and Haedrich, R.L. (2000). Relationships among fat weight, body weight, water weight and condition factors in wild Atlantic salmon parr. Trans. Am. Fish. Soci. 129: 527-538.

Thierry, C.; Sadovy, Y.; Fennessy, S.; Choat, J. H.; Ferreira, B.; Bertoncini, A. A.; Craig, M. T. and Rocha, L. (2008). Epinephelus aeneus. In: IUCN 2011, IUCN Red List of Threatened Species. Available at www.iucnredlist.org (accessed 04 Jan. 2012).

Tsoumani, M.; Liasko, R.;Moutsaki, P.; Kagalou, I. and Leonardos, I.( 2006). Length-weight relationships of an invasive cyprinid fish (Carassius gibelio) from 12 Greek lake sin relation to their trophic states. Journal of Applied Ichthyology, 22: 281-284.

Turan, C.; Gürlek, M.; Uyan, A. and Doğdu, S.A. (2017). Some Biological Characteristics of the White Grouper Epinephelus aeneus from the Iskenderun Bay, Northeastern Mediterranean. The 3rd International Symposium on Euro Asian Biodiversity 05-08 July 2017, Minsk - BELARUS

Vazzoler, A.E.A. (1996). Biologia da reprodução de peixes Teleósteos: teoria e prática. EDUEM, SBI, Maringá

Waly N.; Khady D.; Ousseynou S.; Papa N. and Jacques, P. (2015). The LengthWeight Relationship and Condition Factor of white grouper (Epinephelus aeneus, Geoffroy Saint Hilaire, 1817) at the south-west coast of Senegal, West Africa. International Journal of Advanced Research, 3 (3): 145-153.

Wooten, R. J. (1990). Ecology of teleost fishes. Kluwer Academic Publ., London,404pp.

Wootton R. J. (1996). Fish ecology. London: Blackie Academy and Professional, Chapman and Hall. 